\title{
Egg production, population structure and biochemical composition of the subantarctic copepod Paraeuchaeta antarctica in the Kerguelen Archipelago
}

\author{
F. Alonzo ${ }^{1, *}$, P. Mayzaud ${ }^{1}$, S. Razouls ${ }^{2}$ \\ ${ }^{1}$ Observatoire Océanologique, Océanographie Biochimique et Ecologie, LOBEPM, ESA-CNRS 7076, BP 28, \\ 06230 Villefranche-sur-Mer, France \\ ${ }^{2}$ Laboratoire Arago, Observatoire Océanologique, URA-CNRS 117, 66630 Banyuls Cedex, France
}

\begin{abstract}
The population structure and reproductive biology of the predatory calanoid copepod Paraeuchaeta antarctica (Giesbrecht, 1902) were investigated in the Kerguelen Archipelago over $1 \mathrm{yr}$. The seasonal frequencies of the various developmental and adult stages showed that the population produces 1 generation per year, with recruitment taking place during the austral spring. Occurrence of females with spermatophores indicated that mating occurred in winter. Counts of eggbearing females and of number of eggs per sac confirmed that the peak of reproduction was from winter to late spring. Seasonal variations in body dry weight, lipid and protein contents of the various developmental and adult stages reflected changes in food availability and the reproduction cycle. $P$. antarctica increased lipid and protein content during spring and summer when prey organisms were abundant. The subsequent loss in winter was associated with the production of eggs. A study of lipid classes showed that lipid accumulations were essentially composed of wax esters, which permitted production of eggs when food conditions were unfavorable. The population dynamics and reproductive biology of $P$. antarctica from Kerguelen are discussed in comparison with the antarctic populations described at South Georgia and off the Antarctic Peninsula, as well as with the northern euchaetiid Euchaeta norvegica.
\end{abstract}

KEY WORDS: Paraeuchaeta antarctica $\cdot$ Population composition · Reproductive biology $\cdot$ Biochemical composition

\section{INTRODUCTION}

During the last 2 decades, antarctic euchaetiids have been recognized as important members of the Southern Ocean ecosystem. Paraeuchaeta antarctica is one of the most common species throughout antarctic and subantarctic waters (Park 1978, 1994, Bradford et al. 1983, Ward \& Wood 1988), and this species dominates the copepod community at Crocker Passage, off the

*E-mail: alonzo@obs-vlfr.fr
Antarctic Peninsula (Hopkins 1985a). The importance of $P$. antarctica is related to its trophic status in food webs, as a carnivorous predator that feeds on other copepods on the one hand (Øresland 1991, Yen 1991) and as food for higher trophic-level plankton feeders on the other hand. This species has been shown to be a major contributor to the diet of amphipods, euphausiids, chaetognaths, fishes (Hopkins 1985b), brittle stars (Dearborn et al. 1986) and sea birds (Bocher 1997).

Only a few studies have been carried out on the reproductive biology of Paraeuchaeta antarctica. Studies on the northern couterpart, Euchaeta norvegica, pro- 
vide information on the reproductive pattern of carnivorous euchaetiids (Bakke 1977, Hopkins 1977, 1982, Hopkins \& Machin 1977, Båmstedt 1979, Mauchline 1994), suggesting a major peak of egg production in winter, supported by lipid reserve of the females. Any further egg production must rely on predatory feeding. In $P$. antarctica, a peak of reproduction was also observed in winter in McMurdo Sound (Littlepage 1964, Bradford 1981). Winter reproduction was confirmed by Ward \& Robins (1987) in South Georgia. However, these studies are limited to 1 or 2 periods of the year and never encompass the complete annual cycle owing to the difficulties in accessing these parts of the world ocean.

The program IOZ (Interaction-Oiseaux-Zooplancton) was designed to follow zooplankton production of a subantarctic ecosystem in relation to hydrology, primary production and predation by sea birds. IOZ provided a good opportunity to study on a seasonal basis the population of Paraeuchaeta antarctica present in the Bay of Morbihan, within the Kerguelen Archipelago (Fig. 1). Here we report the seasonal variations in population structure and reproduction strategy. Our aim is to define the season of reproduction. Seasonal changes in the organic content of individuals are investigated to estimate the relative contribution of female storage reserves to the energy requirement of egg production.

\section{MATERIALS AND METHODS}

Sample collection. Paraeuchaeta antarctica was sampled in the Morbihan Bay at IOZ Stn $6\left(49^{\circ} 53^{\prime} \mathrm{S}\right.$, $69^{\circ} 96^{\prime}$ E). Sampling was carried out from January 1996 until April 1997 at monthly intervals in winter and at $15 \mathrm{~d}$ intervals in summer. The net used was an ORI net (1 mm mesh aperture; $1.6 \mathrm{~m}$ diameter) (Omori 1965).

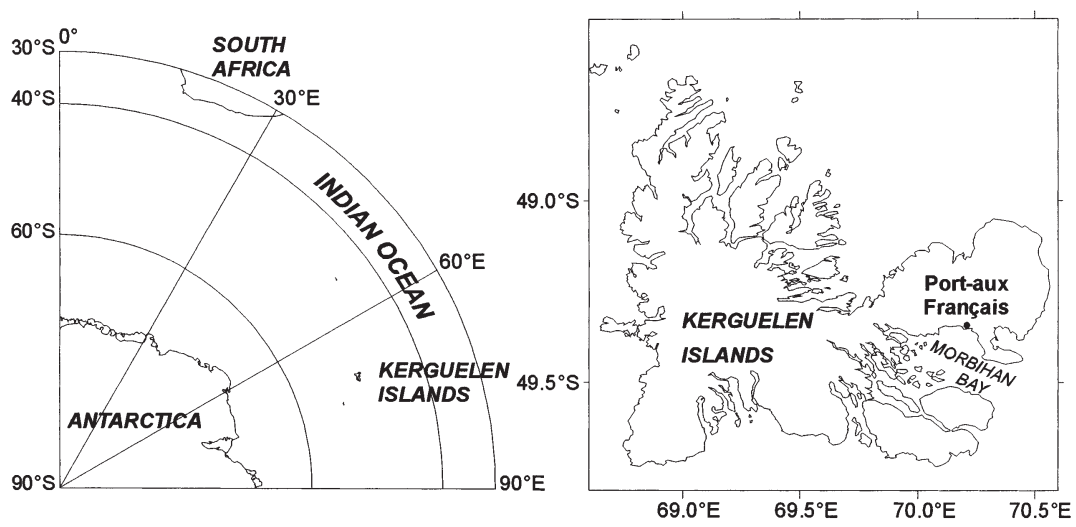

Fig. 1. Geographical location of Kerguelen Islands in the Indian sector of the Southern Ocean, showing location of Morbihan Bay in the archipelago
Oblique hauls from the bottom (140 $\mathrm{m}$ depth) to the surface were performed. Zooplankton were fixed immediately in $10 \%$ neutralized formaldehyde made up with seawater. Undamaged individuals were collected by short surface hauls for biochemical analyses and frozen.

Population study. Copepodite stages (C3, C4, C5) and adults were sorted from random sub-samples. A total of 500 to 1200 individuals were examined on each sampling occasion. For C4, C5 and adults, males and females were separated and counted, and their respective proportions calculated. C4 stages were not quantitatively retained by the ORI net as mean prosome length was $\sim 4 \mathrm{~mm}$ for this stage. Therefore, the proportion of $\mathrm{C} 4$ stages was probably underestimated, but was used as an index of the real abundance of $\mathrm{C} 4$ in the population. Adult females were analysed to determine the frequency of the different breeding stages (Ward \& Robins 1987): prespawning (with developing eggs visible in the ovarian diverticula), egg-bearing (carrying 1 egg sac), and 'interbrood', i.e. those females not in prespawning nor in egg-bearing stages. This category corresponded to females in the interval between 2 broods, as most of the females (almost $90 \%$ ) were shown experimentally to produce several successive broods (Alonzo et al. 2000, in this issue). Occurrence of spermatophores was also recorded. Some egg sacs were detached from females during collection and preservation. Isolated egg sacs were counted and eggbearing females numbers were adjusted accordingly. Intact egg sacs were removed, and the number of eggs per sac were counted.

Body dry weight and biochemical content of developmental and breeding stages. Body weight, lipid and protein contents were determined for each developmental and breeding stage on an annual cycle. Live individuals were sorted, rinsed with $4.5 \%$ ammonium formate, and transferred to pre-weighed aluminum pans. Five adult females or 10 individuals of other stages were used in each pan; triplicate analyses were done. Samples were desiccated at $60^{\circ} \mathrm{C}$ for $2 \mathrm{~d}$ and weighed for body dry weight determination. Lipid and protein extractions and quantifications were performed in triplicate for each developmental stage. Lipids were extracted using the chloroformmethanol-water system of Bligh \& Dyer (1959) as modified by Mayzaud \& Martin (1975). For each extraction, 3 adult females and 5 individuals of other stages were used. A fraction of the extracted lipids were used immediately for spectrophotometric quan- 
tification according to Barnes \& Blackstock (1973). The optical density of sulfophosphovanillin was found to be 1.81-fold higher with lipids extracted from Paraeuchaeta antarctica, than with commercial cholesterol at equal concentrations. Therefore, we chose not to use this classic commercial standard. The sulfophosphovanillin optical density was calibrated using total lipids extracted from $P$. antarctica provided at known concentrations (as determined by gravimetry). Total lipids were evaporated in a water bath $\left(30^{\circ} \mathrm{C}\right)$ under a stream of nitrogen. The dried residue was stored at $-80^{\circ} \mathrm{C}$ under nitrogen until the subsequent Nile red fluorometric assay. Proteins were extracted in $\mathrm{NaOH} 0.5 \mathrm{~N}$ and quantified using folin-phenol reagent according to the Lowry et al. method (1951). Two individuals were used for each measurement.

Lipid composition of developmental and breeding stages. The ratio of neutral/polar lipids can be used as an index of energy storage and feeding condition (Hakanson 1984). A spectrofluorometric method for quantification of neutral and polar lipids in zooplankton was recently developed using Nile red as a fluorescent tag (Alonzo \& Mayzaud 1999). In Paraeuchaeta antarctica, neutral lipids were mainly wax esters and a small proportion of triacylglycerols. Polar lipids were essentially phospholipids. Standard equations relating fluorescence to lipid concentrations were specifically established for $P$. antarctica and used to quantify the seasonal changes in lipid compositions for all developmental and breeding stages.

Four replicate measurements were performed for each lipid extract (3 extracts for each developmental stage present at a given date). For each measurement, a fraction was transferred into a tube and evaporated. The residue was diluted with $50 \mu \mathrm{l}$ of isopropanolchloroform 19:1 and made up to $5 \mathrm{ml}$ with distilled water. The final concentration of the working solution was 5 to $10 \mu \mathrm{g} \mathrm{ml}^{-1}$. Further details of the staining procedure and fluorescence measurement are described in Alonzo \& Mayzaud (1999). Total lipid concentration appeared in good agreement with that obtained with photometric assays (Fig. 2) $(y=0.9297 x$; $\mathrm{n}=64, \mathrm{R}^{2}=0.99, F=5099, \mathrm{df}=1$ and 64, $\mathrm{p}<0.001)$.

Egg dry weight and size. Egg dry weight and size was studied from January 14, 1997, to March 3, 1998. On each collection date, 3 egg sacs were isolated from egg-bearing females. For each sac, eggs were counted and their diameter measured. After desiccation, dry weight

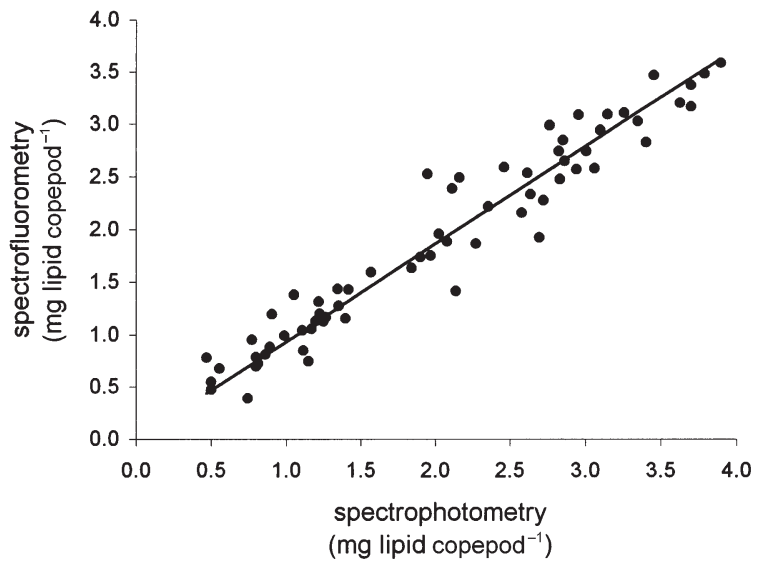

Fig. 2. Paraeuchaeta antarctica. Comparison of spectrofluorometric (Alonzo \& Mayzaud 1999) and spectrophotometric

(Barnes \& Blackstock 1973) quantifications of total lipids

was measured in aluminum pans as described in the foregoing subsection.

Data analysis. The F-test (Sokal \& Rohlf 1981) was used to test the significance of the various described relationships (linear regression). Differences between samples were tested using either an F-test (ANOVA) or nonparametric tests, Kruskal-Wallis $H$-test and MannWhitney $U$-test (Sokal \& Rohlf 1981). In all cases, the alpha level was 0.05 .

\section{RESULTS}

\section{Frequency of developmental stages}

Seasonal changes of the frequency of developmental stages in Paraeuchaeta antarctica are shown in Fig. 3.
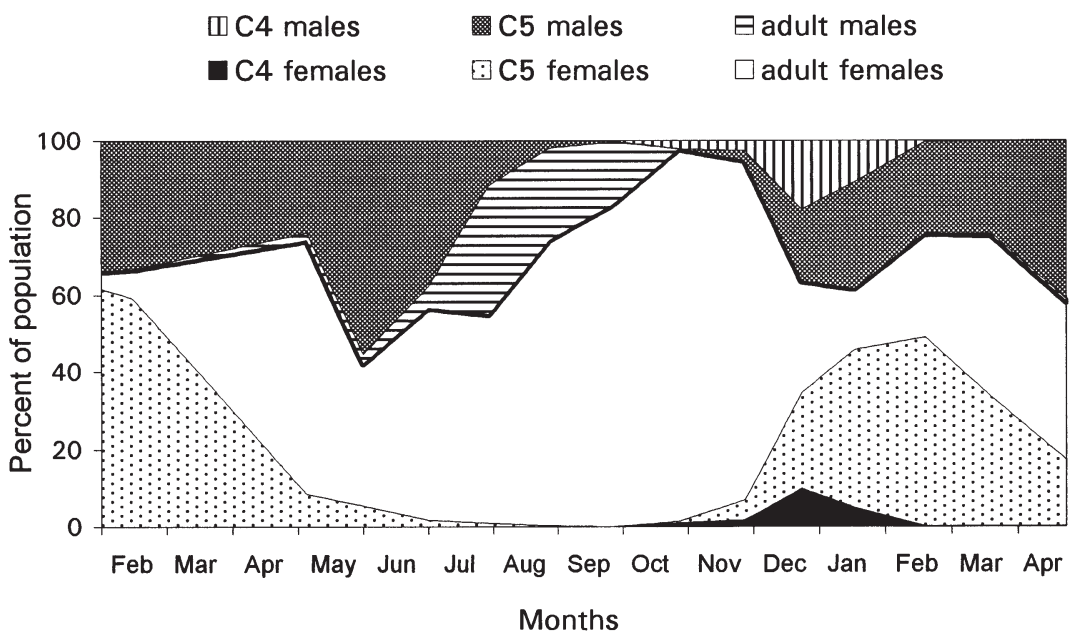

Fig. 3. Paraeuchaeta antarctica. Population composition. Percentages of various developmental stages (C4 and C5) and adults by sex (\% of total individuals), during course of 1 yr (January 1996 to April 1997). Bold line delimits sexes 
In October, C4s appeared in a population almost entirely composed of adult females, and reached their maximum proportion in December. They were quicky replaced by C5 stages, which appeared in November, 1 mo after the C4s. In January and February, the population was almost completely composed of C5 stages (95\% in 1996 and $85 \%$ in 1997). The peak frequency of C5 females was reached on these dates, while that of C5 males occurred later, in June. From February to May, all the females moulted progressively to the adult stage. Moulting to adult males began slowly in May, but the process was accelerated in July when this stage quickly reached its maximum. C5 males remained present until the end of August. Adult males were present for another $2 \mathrm{mo}$, but disappeared during October. The successive predominance of adult stages (September) and C5s (January) indicated that $P$. antarctica from Kerguelen completed a single generation per year. The sex ratio as percent males in the total population varied from $35 \%$ in January to $58 \%$ in June (the period of maximal abundance of C5 males). It then decreased progressively to $1 \%$ in October, when adult males disappeared.

\section{Reproduction season}

The occurrence of females with spermatophores showed that mating took place in the presence of adult males (March to October) (Fig. 4). Even when males accounted for only $5 \%$ of the population, $25 \%$ of the females were recorded with spermatophores (July). The frequency of females with spermatophores varied between 15 and $25 \%$ from July to October, and remained under $5 \%$ during the rest of the reproductive season.

The frequency of the different breeding stages of females, i.e. 'prespawning', 'egg-bearing' and 'inter-

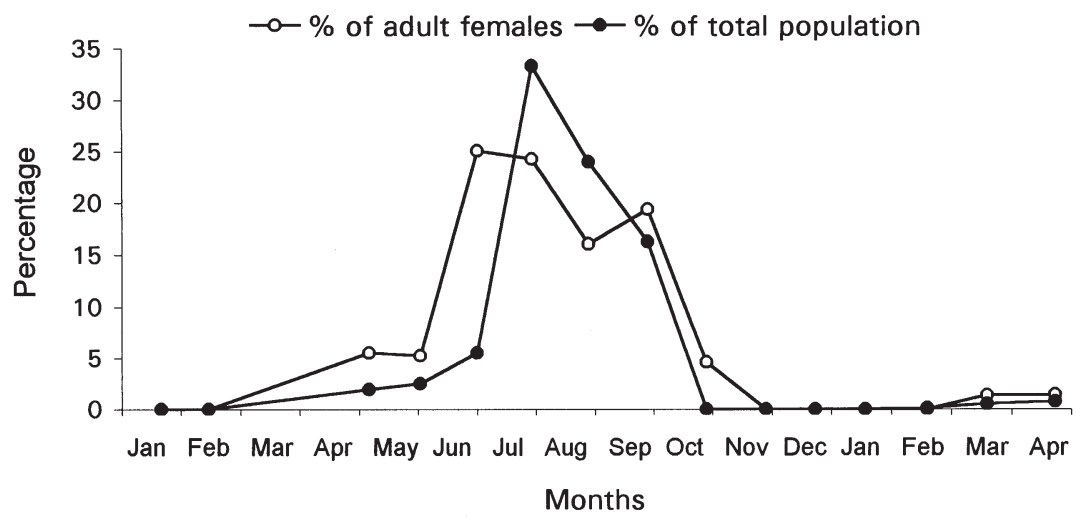

Fig. 4. Paraeuchaeta antarctica. Mating season. Percentage of adult males (•, $\%$ of total individuals) and percentage of adult females with spermatophore(s) ( $0, \%$ of total adult females), over an annual cycle brood' (Fig. 5) showed that females reproduced from July to December. Some egg-bearing females could be observed between January and July, but accounted only for a small fraction of the population $(<5 \%)$. The peak frequency of spawning females (66\% of the population) was reached at the end of August. At this date, a fraction of females (11\%) was simultaneously 'prespawning' and 'egg-bearing', providing further evidence that maximum egg production occurred during this period.

The number of eggs per female showed strong variability within samples. Changes during the seasonal cycle were significant ( $\mathrm{n}=300, H=184 \mathrm{p}<0.001$, with $\mathrm{df}=14$ ), with mean values from $\sim 30$ eggs per sac in January to 70 eggs per sac at the end of August (Fig. 6). The number of eggs per female followed the pattern observed for frequency of breeding females (Fig. 5), with maximum values recorded between July and December.

\section{Body dry weight of developmental and breeding stages}

Body dry weight changes during a complete season cycle are shown in Fig. 7. Similar patterns of changes in dry weights were recorded for all stages, with increasing values in summer (between October and March) and decreasing values in winter (from May to October). As egg production had reached its maximum, dry weight of adult females in August and September could only be measured for prespawning stages, which were $\sim 1.5 \mathrm{mg}$ heavier than interbrood females from July and October. The sexual dimorphism observed in adults (maximum of $6.61 \mathrm{mg}$ per interbrood females and $2.40 \mathrm{mg}$ per adult male) could also be detected in the C5 stage: $3.64 \mathrm{mg}$ per female and $2.74 \mathrm{mg}$ per male. In December and January, mean dry weights recorded for $\mathrm{C} 4$ and C3 stages were 1.90 and $0.54 \mathrm{mg}$ ind. $^{-1}$, respectively.

\section{Biochemical content of developmental and breeding stages}

Body lipid and protein contents varied during the seasonal cycle in parallel with the pattern observed for dry weight (Fig. 7). However, in all stages, protein content showed a lower amplitude of variation than lipid (Table 1). Thus, for adult females and C5 stages, lipids ind.-1 showed maximal values at the end of 
summer. Similarly, maxima for proteins were recorded in April for C5 stages and in February for adult females. For both compounds, minimal values were recorded at the end of winter. The single measurement performed in December for C4 stages yielded $0.56 \mathrm{mg}$ lipid and $0.95 \mathrm{mg}$ protein ind. ${ }^{-1}$.

Changes in dry weight were strongly associated with changes in lipid and in protein contents and showed no correlation with body size $\left(\mathrm{n}=11, \mathrm{R}^{2}=0.037, \mathrm{p}>0.05\right)$. Linear relationships were revealed between lipid and/or protein content and dry weight, with high degrees of significance (Fig. 8). When lipids and proteins were expressed as percentage dry weight, it could be seen that proportion of lipids varied significantly as a function of dry weight. Hence, heavy individuals had a greater proportion of lipid $(>50 \%)$ than light individuals $(\sim 30 \%)$. The proportion of proteins was independent of dry weight; consequently, lipid to protein ratios changed strongly in relation to development and season: from 0.75 in December to 1.00 in April in C5 females; from 0.75 in October to 1.15-1.25 in May for adult females; from 0.5 to 0.8 in males from Stage C5 to adult.

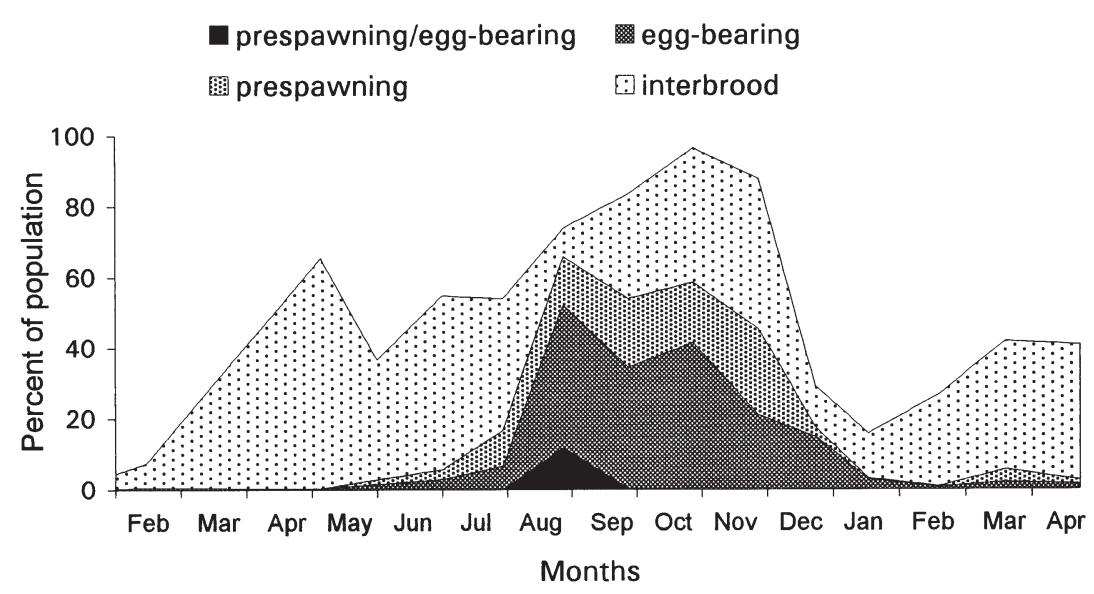

Fig. 5. Paraeuchaeta antarctica. Breeding season. Percentages of various breeding stages of adult females (\% of total population) over an annual cycle

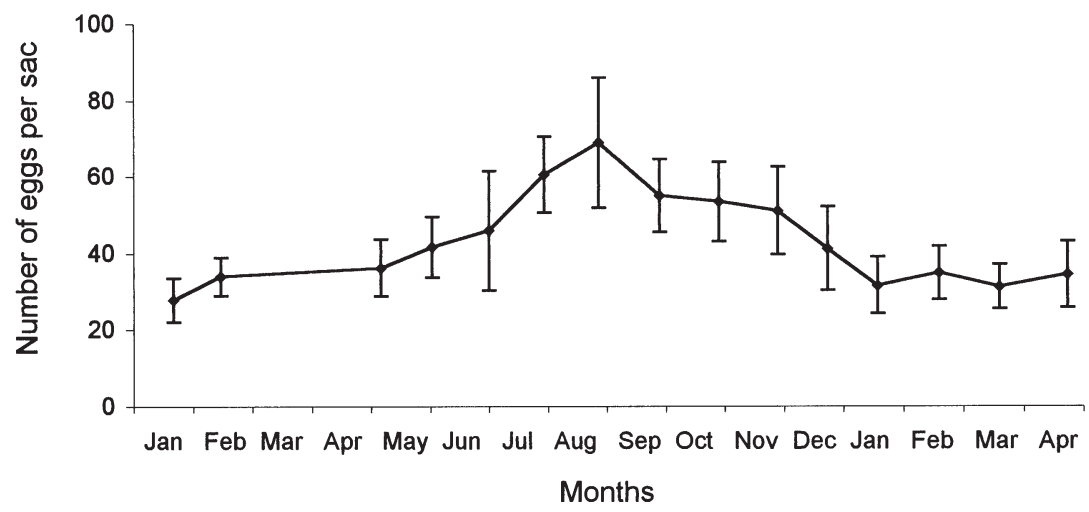

Fig. 6. Paraeuchaeta antarctica. Fecundity. Mean number of eggs per sac over an annual cycle. Error bars $= \pm \mathrm{SD}$

Table 1. Paraeuchaeta antarctica. Body lipid and protein content $\left(\mathrm{mg}\right.$ ind.$\left.^{-1}\right)$ of the various developmental and breeding stages. Maximum, Minimum: highest and lowest monthly mean measured in each stage, respectively

\begin{tabular}{|c|c|c|c|c|c|c|}
\hline \multirow[t]{2}{*}{ Stage } & \multicolumn{3}{|c|}{ Maximum } & \multicolumn{3}{|c|}{ Minimum } \\
\hline & Month & Mean & $\mathrm{SD}$ & Month & Mean & $\mathrm{SD}$ \\
\hline \multicolumn{7}{|l|}{ Lipids } \\
\hline C5 female & May & 1.42 & 0.16 & January & 0.77 & - \\
\hline C5 male & May & 1.15 & 0.02 & January & 0.50 & - \\
\hline Interbrood female & April & 3.63 & 0.20 & October & 1.25 & 0.21 \\
\hline Prespawning female & April & 3.79 & 0.08 & September & 1.84 & 0.16 \\
\hline Egg-bearing female & April & 3.90 & 0.37 & September & 1.57 & 0.16 \\
\hline \multicolumn{7}{|l|}{ Proteins } \\
\hline C5 female & April & 1.76 & 0.18 & January & 0.96 & 0.23 \\
\hline C5 male & April & 1.36 & 0.08 & January & 1.03 & 0.24 \\
\hline Interbrood female & February & 3.01 & 0.29 & October & 1.53 & 0.21 \\
\hline Prespawning female & February & 3.66 & 0.10 & October & 1.59 & 0.11 \\
\hline Egg-bearing female & February & 3.85 & 0.22 & October & 2.03 & 0.37 \\
\hline
\end{tabular}



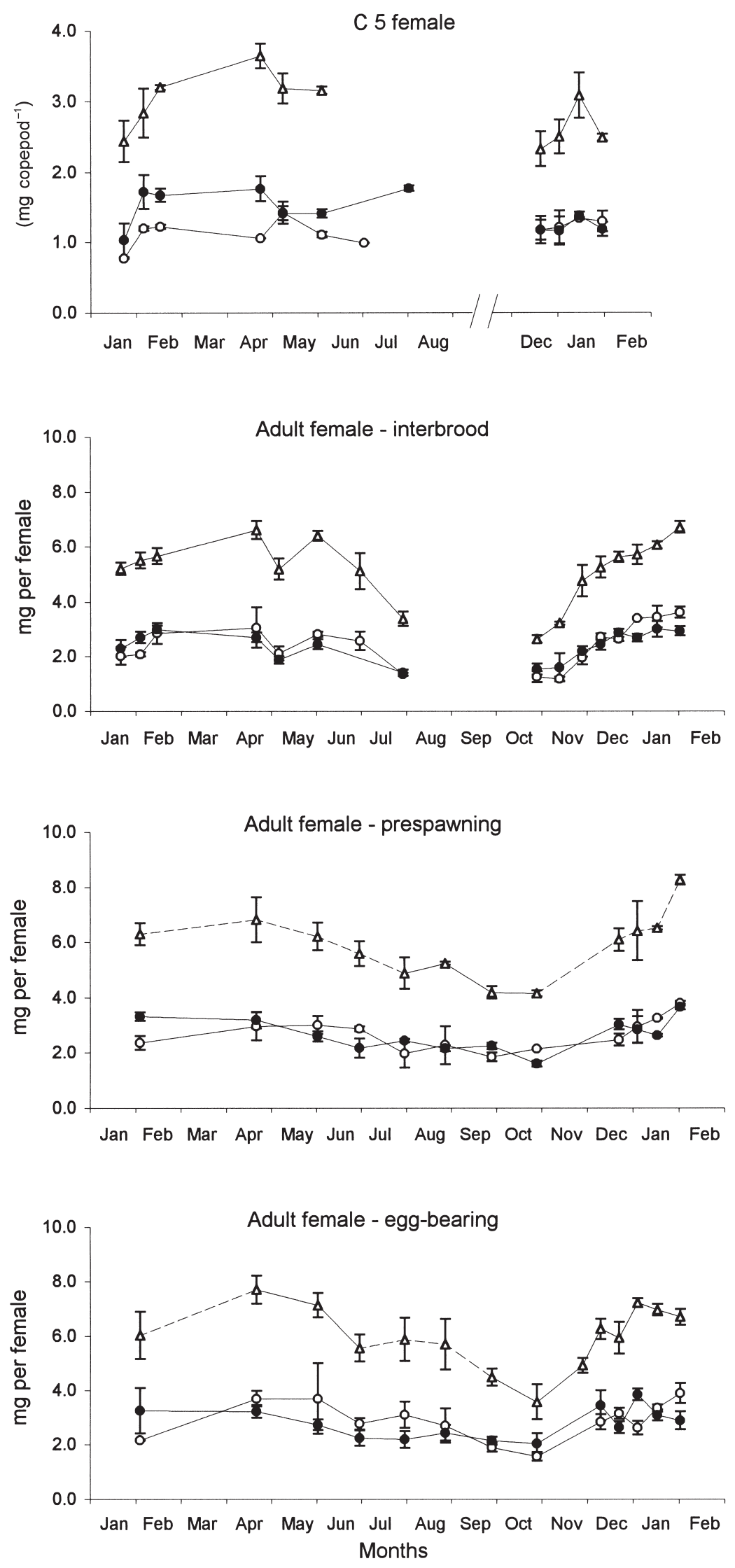
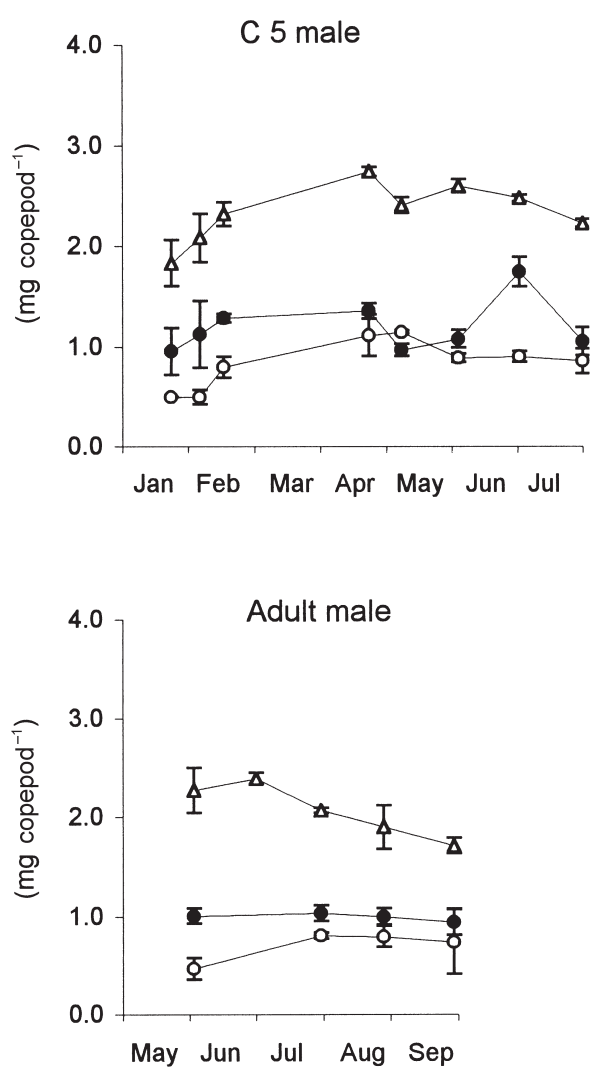

Fig. 7. Paraeuchaeta antarctica. Seasonal variation in body dry weight $(\Delta)$, lipid (0) and protein $(\bullet)$ contents $\left(\mathrm{mg}\right.$ ind.$\left.^{-1}\right)$ of various developmental stages. Dashed lines show calculated dry weight, assuming that sum of lipid and protein contents accounts for $90 \%$ dry weight. Error bars $= \pm$ SD 

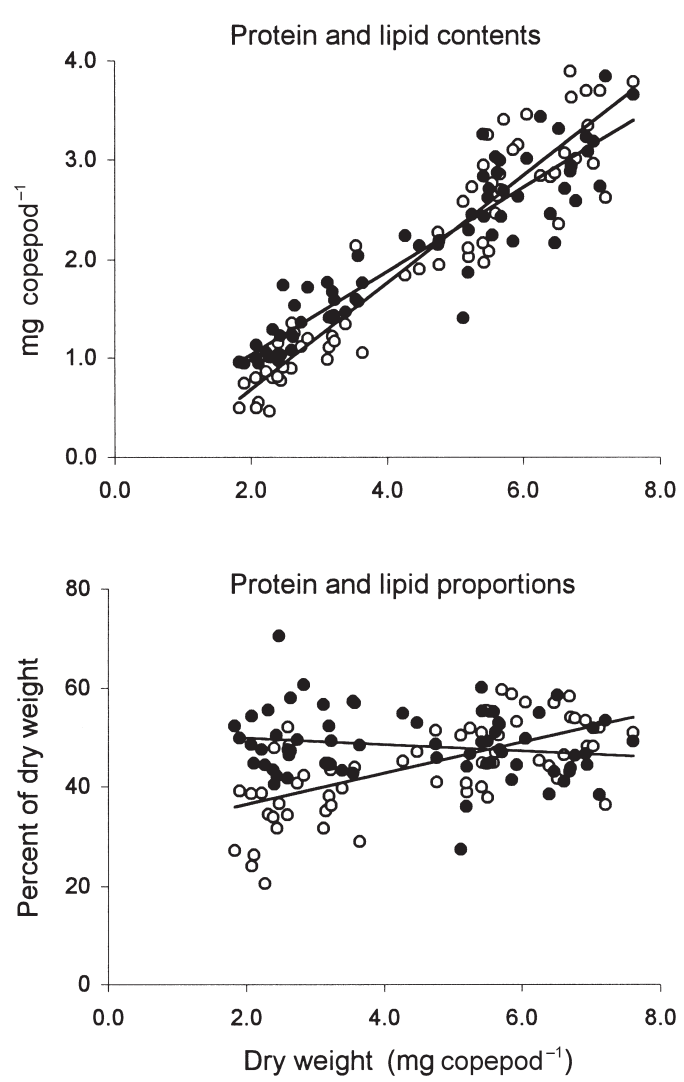

Fig. 8. Paraeuchaeta antarctica. Changes in lipid (o) and protein $(\bullet)$ content and percentage in relation to body dry weight. Lipid content: $y=0.5391 x-0.3952, \mathrm{R}^{2}=0.89, F=514$, $\mathrm{df}=1$ and $63, \mathrm{p}<0.001$; protein content: $y=0.4223 x+0.19$, $\mathrm{R}^{2}=0.85, F=364, \mathrm{df}=1$ and $63, \mathrm{p}<0.001$; lipid percent: $y=$ $3.1362 x+30.174 ; \mathrm{R}^{2}=0.36, F=36.8, \mathrm{df}=1$ and $63, \mathrm{p}<0.001$; protein percent: $y=-0.6424 x+51.042 ; \mathrm{R}^{2}=0.01, F=1.85$, $\mathrm{df}=1$ and $63, \mathrm{p}=0.18$

\section{Seasonal changes in lipid composition of developmental and breeding stages}

Neutral and polar lipids in developmental stages were estimated over the annual cycle. Fig. 9 shows that the content of neutral lipids strongly followed the seasonal changes in total lipids whereas polar lipids stayed constant over the year within a developmental stage. Mean proportions of polar lipids (percent of total lipids) are reported in Table 2 for summer and winter periods. Mean values were compared using nonparametric tests (Table 3). Polar lipid percentages were significantly different between summer and winter within any one female breeding stage. Independently of season, polar lipid proportions varied significantly between breeding stages in females, and between developmental stages in both females and males. A significant difference was detected in relation to sex in the adult stage (breeding stages pooled together) but not in the C5 stage.
Concentrations of both lipid classes were correlated with total lipid content (Fig. 10). The relationship between neutral lipids and total lipids was linear, with a high degree of significance. Similarly, polar lipids were linearly related to total lipids, but this relationship was characterized by a smaller slope and $\mathrm{R}^{2}$ than that with neutral lipids.

\section{Egg dry weight and size}

Dry weight and diameter of eggs were significantly different between samples: $\mathrm{n}=68, H=55, \mathrm{p}<0.001$, with $\mathrm{df}=24$ for weight; $\mathrm{n}=74, H=47, \mathrm{p}=0.003$, with $\mathrm{df}=24$ for size. However, these changes showed no seasonal trend; furthermore, weight could not be related significantly to size. Annual means led to a dry weight of $17.4 \mu \mathrm{g}$ per egg and diameter of $388 \mu \mathrm{m}$.

\section{DISCUSSION}

In the present study, Paraeuchaeta antarctica from Kerguelen was shown to complete a single generation per year. Although the proportion of C4s was underestimated, our observations were consistent with those from samples collected using a WP2-net (Razouls unpubl. data). The concomitant presence of younger copepodite stages (C1 to C3) from September to January suggested that the recruitment period of the new generation took place from spring to the beginning of summer. In good agreement with this observation, reproduction of $P$. antarctica at Kerguelen was based on 1 period of egg production from winter to late spring. In populations from South Georgia, 2 generations per year were proposed by Ward \& Robins (1987), initiated by 2 distinct peaks of egg production (in summer and in winter). However, their conclusions were based on observations from limited time periods during the annual cycle. In Euchaeta norvegica from western Norway, 2 generations per year were also identified, and these generations were characterized by pronounced differences in development rates (Bakke 1977) and in bioenergetic budgets (Båmstedt 1979).

The values that we observed for sex ratio and spermatophore occurrence were consistent with those reported by Ward \& Robins (1987) in South Georgia. The longevity of adult males was much shorter (1 to $2 \mathrm{mo}$ ) than that of adult females (6 to $7 \mathrm{mo}$ ), and might be associated with the fact that adult males do not feed (Yen 1991). Therefore, the progressive moulting to adult males was essential for their survival later in the season in spite of their relatively short longevity. The frequency of females with spermatophores (up to $25 \%$ of the females) were relatively low, compared with the 

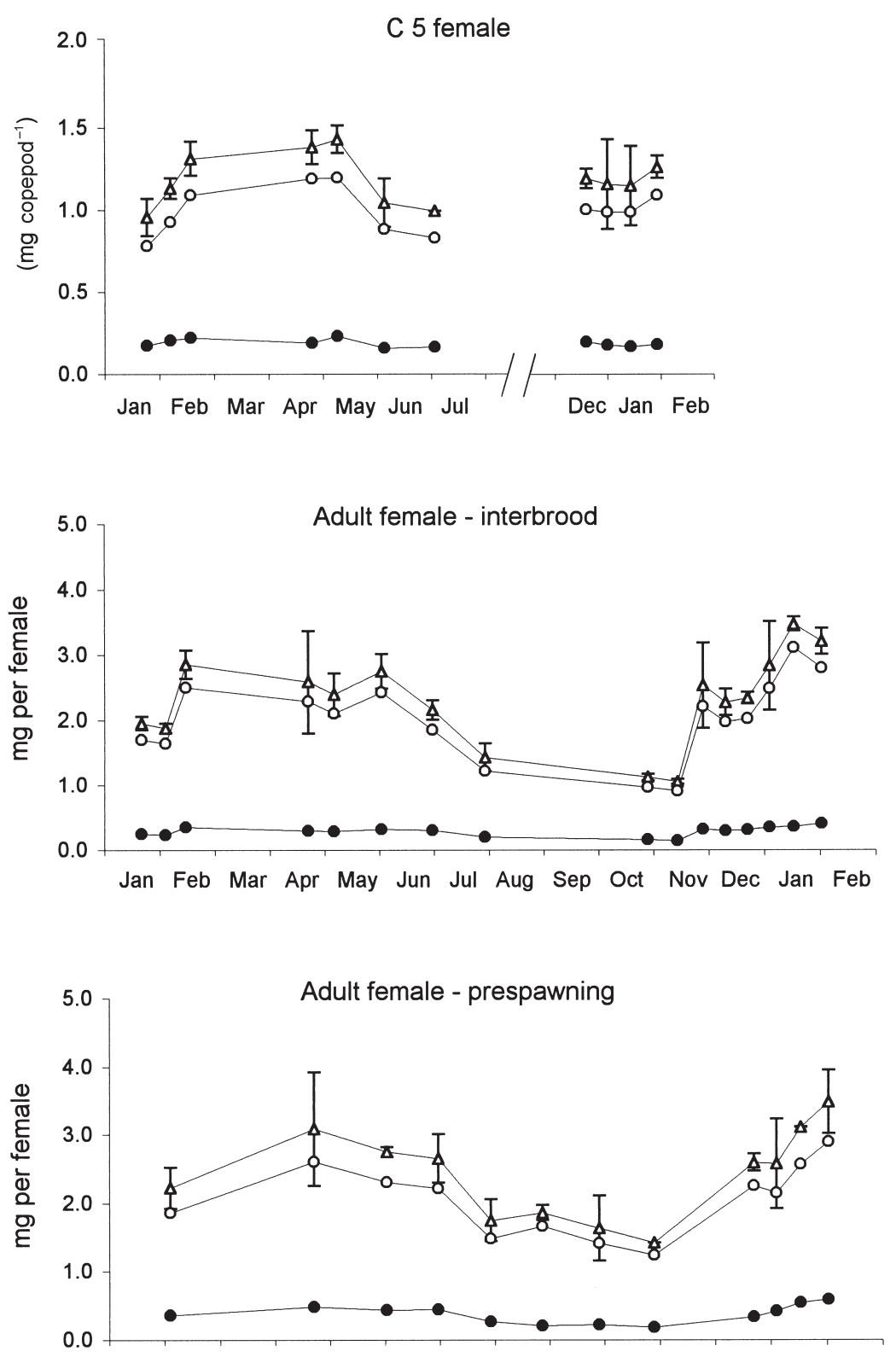

Jan Feb Mar Apr May Jun Jul Aug Sep Oct Nov Dec Jan Feb

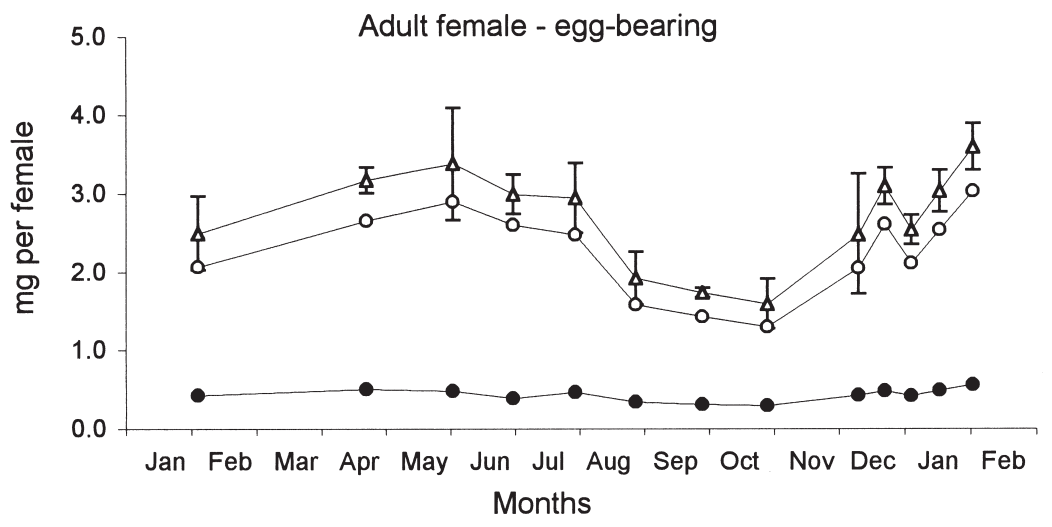

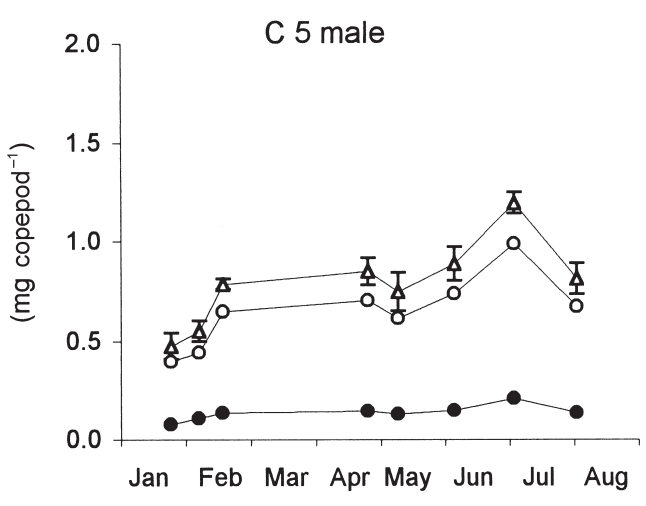

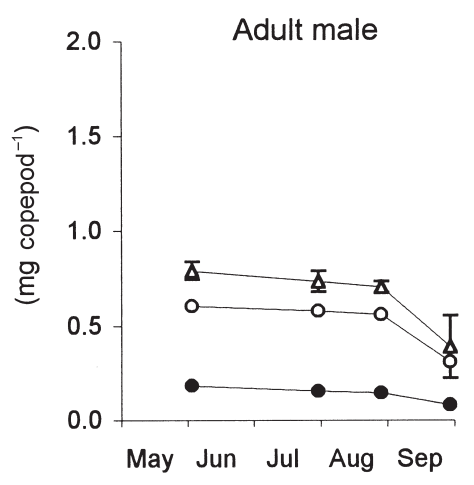

Fig. 9. Paraeuchaeta antarctica. Seasonal variation in total $(\Delta)$, neutral ( $(0)$ and polar $(\bullet)$ lipid contents (mg ind. ${ }^{-1}$ ) of various developmental and breeding stages, estimated using Nile red method. Error bars $= \pm \mathrm{SD}$ 
Table 2. Paraeuchaeta antarctica. Percentage of polar lipids (as percent of total lipids) in the various developmental and breeding stages. Dates presented as $\mathrm{mo} / \mathrm{d} / \mathrm{yr}$

\begin{tabular}{|lccc|}
\hline \multirow{2}{*}{ Stage } & \multicolumn{2}{c}{ Winter period } & \multicolumn{2}{c|}{ Polar lipids (\%) } \\
& & Winter & Summer \\
\hline Interbrood female & $07 / 01 / 96$ to 01/01/97 & 13.4 & 12.0 \\
Prespawning female & $08 / 28 / 96$ to $12 / 20 / 96$ & 16.3 & 12.6 \\
Egg-bearing female & $08 / 28 / 96$ to $12 / 20 / 96$ & 16.4 & 15.9 \\
Adult males & - & 21.1 & - \\
C5 females & - & - & 15.8 \\
C5 males & - & - & 17.3 \\
C4 & - & & \\
\hline
\end{tabular}

Table 3. Paraeuchaeta antarctica. Comparison of polar lipid proportions in the various developmental and breeding stages in relation to season, development, sex and breeding stage. Mann-Whitney $(U)$ or Kruskal-Wallis $(H$, with df $=2)$ tests were used

\begin{tabular}{|llccc|}
\hline Factor & Stage & $\mathrm{n}$ & $U$ & $\mathrm{p}$ \\
\hline Season: & Interbrood female & 41 & 110 & 0.011 \\
summer vs winter & Prespawning female & 29 & 146 & 0.002 \\
& Egg-bearing female & 35 & 78.5 & 0.039 \\
Development: & Females & 153 & 3397 & 0.001 \\
C5 vs adult & Males & 67 & 66 & 0.001 \\
Sex: & Adult & 114 & 68 & $<0.001$ \\
female vs male & C5 & 48 & 199 & 0.090 \\
Breeding stage & Females & 105 & $H=31$ & $\mathrm{p}<0.001$ \\
\hline
\end{tabular}

$50 \%$ observed for Euchaeta norvegica (Hopkins \& Machin 1977, Mauchline 1994). Three hypotheses can explain such a low proportion of mated females: (1) accidental detachment of spermatophores occurs during sampling; (2) mating males select females about to breed (this was not observed); (3) time of spermatophore attachment to the female is short and remating is necessary. Such remating would increase the chances of functional spermatophore placement (i.e. correctly linked to the genital pore) on the females. This third hypothesis is in good agreement with our observation of up to 6 to 7 spermatophores on 1 female (data not shown). Such a great number of spermatophores on 1 female was also observed at South Georgia by Ward \& Robins 1987). These authors proposed a sperm storage in 'alternatively placed' spermatophores (i.e. spermatophores not directly placed onto the female genital field) which is inconsistent with a short duration of spermatophore attachment.

In zooplankton, seasonal variations in body carbon and nitrogen content have been shown to reflect changes in food availability and reproduction cycle (Hopkins et al. 1984). In particular, the role of lipids as an energy store in calanoids from high latitudes has been clearly illustrated (Sargent \& Henderson 1986, Ohman et al. 1989). In the present study, Paraeuchaeta antarctica increased amounts of stored lipid during spring and summer. The subsequent loss in winter was associated with the peak in egg production. As proteins showed approximately constant proportions of body mass $(50 \%)$, the lipid to protein ratio changed in response to the developmental and reproductive patterns. The pattern described by Littlepage (1964) in $P$. antarctica from McMurdo was similarly associated with reproduction activity, with maximum lipid accumulation recorded later (August). Seasonal changes in the lipid to protein ratio were similar to those in adult females of Euchaeta norvegica (Båmstedt \& Matthews 1975).

The difference in lipid composition observed between sexes was related to the ability of females to store large amounts of neutral lipids during development. Conversely, adult males showed lower lipid contents than subadult male stages. In adult females, egg production induced a strong decrease in lipid content and consequently in neutral lipid proportion. In fact, fat females from late summer showed a lower polar

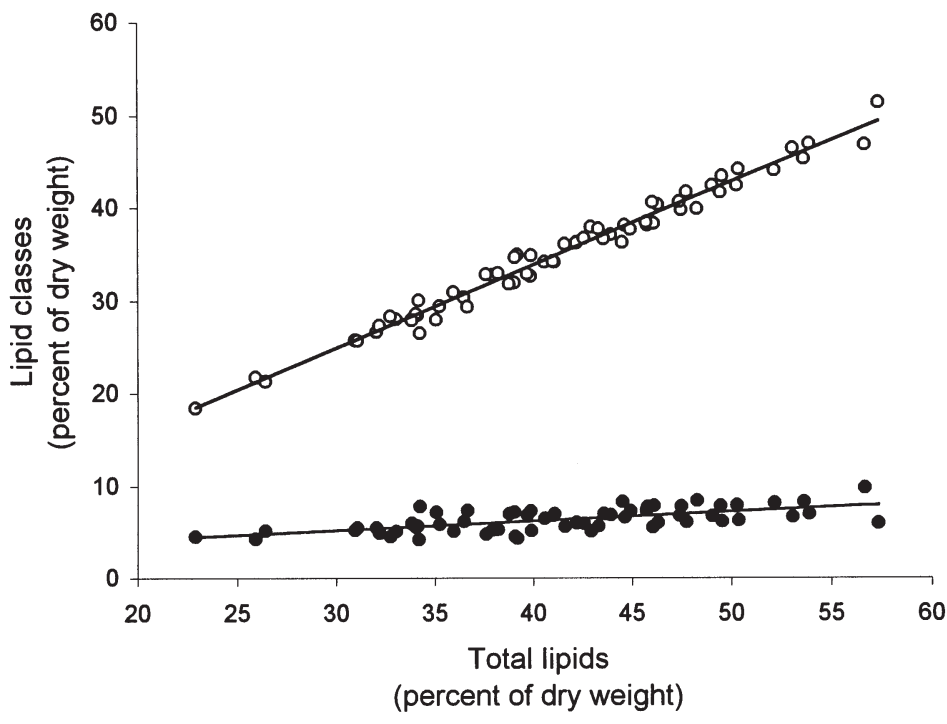

Fig. 10. Paraeuchaeta antarctica. Changes in neutral (o) and polar (•) lipid percentage (\% of total lipids), in relation to total lipids (\% dry weight). Neutral lipids: $y=0.8972 x-2.0633 ; \mathrm{n}=64, \mathrm{R}^{2}=0.98, F=3157$; polar lipids: $y=0.1028 x+2.0633 ; \mathrm{n}=64, \mathrm{R}^{2}=0.39, F=41.2$. In both cases, $\mathrm{p}<0.001$, with $\mathrm{df}=1$ and 62 
lipid content than spent females from winter. Breeding females (prespawning and/or egg-bearing) showed higher polar lipid proportions than interbrood females. This difference could be explained by reproductive needs: although wax esters dominate the composition of eggs (Lee et al. 1974), membranes, required for egg production, are essentially composed of polar lipids. The pattern was different in Euchaeta japonica, which displayed a maximum proportion of neutral lipids in the C5 stage, and a lower proportion of neutral lipids in immature than in mature females (Lee et al. 1974).

Trends observed for egg production at Kerguelen were similar to those reported for South Georgia (Ward \& Robins 1987) with the proportion of egg-bearing females (vs total females) and brood size greater in winter than in summer at both locations (Table 4). In Kerguelen, these seasonal differences were associated with the end of reproduction in summer. However, winter reproduction displayed differences related to geographical location: (1) the number of eggs per sac was lower in the Kerguelen population than in the South Georgian population; (2) a lower proportion of egg-bearing females was observed in South Georgia; (3) Paraeuchaeta antarctica in South Georgia produced eggs with smaller lipid reserves than in Kerguelen (related to the difference in egg dry weight). The lower proportion of egg-bearing females in South Georgia strongly suggested that females from the second generation did not reproduce in winter and led to the subsequent summer peak of egg production. In parallel with these differences, female lipid reserves were larger at South Georgia than in Kerguelen, suggesting that food availability in the Morbihan Bay was not sufficient during summer for females to accumulate maximal energy reserves. This sub-optimal accumulation of reserves might explain the smaller brood sizes observed in Kerguelen compared to those reported for South Georgia. In fact, as a result of this combination of greater female and brood weights at South Georgia, relative brood weight (vs dry weight of prespawning females) remained unchanged in winter between the 2 locations.

We interpreted the differences in the reproductive biology (number of generations per year, reproduction rates) as a response to seasonal variations in food availability, which are more pronounced in Kerguelen than in South Georgia (Atkinson \& Peck 1988, Ward 1989, Razouls et al. 1996). No general changes in feeding by Paraeuchaeta antarctica were demonstrated between seasons in South Georgia (Øresland \& Ward 1993), where the species completed 2 generations per year (Ward \& Robins 1987). In the Kerguelen population, a second generation initiated by summer reproduction would lead to an unsuccessful recruitment in winter when food availability is low. P. antarctica reproduced only during winter and spring, using a dual source of energy: from June to October, reproduction was supported by accumulated reserves (present study) and predatory feeding occurred and provided at least $50 \%$ of energy requirements (Alonzo et al. 2000); from October to January, the increasing dry weight of females suggested that reproduction relied only on predatory feeding during late spring. This contrasts with the situation observed during winter in Gerlache Strait (Antarctic Peninsula), where predatory feeding was clearly arrested (Yen 1991) and reproduction relied only on maternal reserves.

In the Kerguelen Archipelago, the life cycle of Paraeuchaeta antarctica is adapted to seasonal variability in food availability. The survival of the species is based on the ability to store large amounts of lipids, mainly wax esters, during the summer feeding period. In late winter, when feeding conditions are unfavorable, this lipid accumulation, supplemented by predation, is used to produce eggs with extended reserves (Alonzo et al. 2000). This strategy ensures the appearance and completion of critical life cycle stages during the subsequent spring and summer, when physical (light, temperature) and biological (food) conditions are favorable to development.

Acknowledgements. We would like to thank Dr M. Ohman and Dr E. Rochelle-Newall for commenting on and editing the manuscript and Mr Gilles Cauvin and Mr Gildas Roudaut for technical assistance. Financial support was provided by 
IFRTP as part of the program IOZ. Our thanks also go to the captains and crews of the RV 'La Curieuse' and to Mr Nicolas Gasco, Loïc Guérin and Pascal Lejeune for their assistance during sampling. The authors are grateful to anonymous referees for their helpful comments on this manuscript.

\section{LITERATURE CITED}

Alonzo F, Mayzaud P (1999) Spectrofluorometric quantification of neutral and polar lipids in zooplankton using Nile red. Mar Chem 67:289-301

Alonzo F, Mayzaud P, Razouls S (2000) Egg-production dynamics, biochemical composition and hatching success of the subantarctic copepod Paraeuchaeta antarctica: laboratory studies. Mar Ecol Prog Ser 205:219-227

Atkinson A, Peck JM (1988) A summer-winter comparison of zooplankton in the oceanic area around South Georgia. Polar Biol 8:463-473

Bakke JLW (1977) Ecological studies on the deep-water pelagic community of Korsfjorden, western Norway. Population dynamics of Euchaeta norvegica (Crustacea, Copepoda) from 1971 to 1974. Sarsia 63:49-55

Båmstedt U (1979) Reproductive bioenergetics within the summer and winter generations of Euchaeta norvegica (Copepoda). Mar Biol 54:135-142

Båmstedt U, Matthews JBL (1975) Studies of the deep-water pelagic community of Korsfjorden, western Norway. The weight and biochemical composition of Euchaeta norvegica Boeck in relation to its life cycle. In: Barnes $\mathrm{H}$ (ed) Proc 9th Eur Mar Biol Symp. Aberdeen University Press, Aberdeen, p 311-327

Barnes H, Blackstock J (1973) Estimation of lipids in marine animals and tissues: detailed investigation of the sulfovanillin method for total lipids. J Exp Mar Biol Ecol 12: 103-118

Bligh EG, Dyer WJ (1959) A rapid method of total lipid extraction and purification. Can J Biochem Physiol 37:911-917

Bocher P (1997) Stratégies de recherche alimentaire comparées chez trois espèces d'oiseaux plongeurs planctonophages. DEA de Biologie du Comportement, Université Paris XIII, Villetaneuse

Bradford JM (1981) Records of Paraeuchaeta (Copepoda: Calanoida) from McMurdo Sound, Antarctica, with a description of three hitherto unknown males. NZ J Mar Freshw Res 15:391-402

Bradford JM, Haakonssen L, Jillett, JB (1983) The marine fauna of New Zealand: pelagic calanoid copepods: Families Euchatidae, Phaennidae, Scolecithricidae, Diaixidae, and Tharybidae. Mem NZ Oceanogr Inst 90:1-150

Dearborn JH, Ferrari FD, Edwards KC (1986) Can pelagic aggregations cause benthic satiation? Feeding biology of the antarctic brittle star Astronoma agassizzii (Echinodermata: Ophiuridea). Antarct Res Ser 44:1-28

Hakanson JL (1984) The long and short term feeding condition in field-caught Calanus pacificus, as determined from the lipid content. Limnol Oceanogr 29:794-804

Hopkins CCE (1977) The relationship between maternal body size and clutch size, development time and egg mortality in Euchaeta norvegica (Copepoda: Calanoida) from Loch Etive, Scotland. J Mar Biol Assoc UK 57:723-733

Hopkins CCE (1982) The breeding biology of Euchaeta norvegica (Boeck)(Copepoda: Calanoida) in Loch Etive, Scotland: assessment of breeding intensity in terms of seasonal cycles in the sex ratio, spermatophore attachment, and egg-sac production. J Exp Mar Biol Ecol 60:91-102

Hopkins CCE, Machin D (1977) Patterns of spermatophore distribution and placement in Euchaeta norvegica (Copepoda: Calanoida). J Mar Biol Assoc UK 57:113-131

Hopkins CEE, Tande KS, Grønvik S, Sargent JR (1984) Ecological investigations of the zooplankton community of Balsfjorden, northern Norway: an analysis of growth and overwintering tactics in relation to niche and environment in Metridia longa (Lubbock), Calanus finmarchicus (Gunnerus), Thysanoessa inermis (Krøyer) and T. raschi (M. Sars). J Exp Mar Biol Ecol 82:77-99

Hopkins TL (1985a) The zooplankton community of Crocker Passage, Antarctic Peninsula. Polar Biol 4:161-170

Hopkins TL (1985b) Food web of an antarctic midwater ecosystem. Mar Biol 89:197-212

Lee RF, Nevenzel JC, Lewis AG (1974) Lipid changes during life cycle of marine copepod Euchaeta japonica Marukawa. Lipids 9:891-898

Littlepage JL (1964) Seasonal variations in lipid content of two antarctic marine Crustacea. In: Carrick R (ed) Biologie antarctique. Hermann, Paris, p 463-470

Lowry OH, Rosebrough NJ, Lewis Farr A, Randall RJ (1951) Protein measurement with Folin-phenol reagent. J Biol Chem 193:265-275

Mauchline J (1994) Seasonal variations in some population parameters of Euchaeta species (Copepoda: Calanoida). Mar Biol 120:561-570

Mayzaud P, Martin JLM (1975) Some aspects of the biochemical and mineral composition of marine plankton. J Exp Mar Biol Ecol 17:297-310

Ohman M, Bradford JM, Jillett JB (1989) Seasonal growth and lipid storage of the circumglobal, subantarctic copepod Neocalanus tonsus (Brady). Deep-Sea Res 36A:1309-1326

Omori M (1965) A 160-cm opening-closing plankton net. I. Description of the gear. J Oceanogr Soc Jpn 21:212-220

Øresland V (1991) Feeding of the carnivorous copepod Euchaeta antarctica in Antarctic waters. Mar Ecol Prog Ser 78:41-47

Øresland V, Ward P (1993) Summer and winter diet of four carnivorous copepod species around South Georgia. Mar Ecol Prog Ser 98:73-78

Park T (1978) Calanoid copepods belonging to the families Aetideidae and Euchaetidae from antarctic and subantarctic waters. Biology of the antarctic seas. VII. Antarct Res Ser 27:91-290

Park T (1994) Geographical distribution of bathypelagic genus Paraeuchaeta (Copepoda: Calanoida). Hydrobiologia 292/293:317-332

Razouls S, Koubbi P, Mayzaud P (1996) Spatio-temporal distribution of mesozooplankton in a sub-antarctic coastal basin of the Kerguelen Archipelago (southern Indian Ocean). Polar Biol 16:581-587

Sargent JR, Henderson RJ (1986) Lipids. In: Corner EDS, O'Hara SCM (eds) Biological chemistry of copepods. Oxford University Press, Oxford, p 59-108

Sokal RR, Rohlf FJ (1981) Biometry. The principles and practice of statistics in biological research, 2nd edn. WH Freeman \& Co, New York

Ward P (1989) The distribution of zooplankton in an Antarctic fjord at South Georgia during summer and winter. Antarct Sci 1:141-150

Ward P, Robins DB (1987) The reproductive biology of Euchaeta antarctica Giesbrecht (Copepoda: Calanoida) at South Georgia. J Exp Mar Biol Ecol 108:127-145

Ward P, Wood GA (1988) The distribution of the Euchaetidae (Copepoda: Calanoida) around South Georgia. Polar Biol 9:45-52

Yen J (1991) Predatory feeding behaviour of an antarctic marine copepod, Euchaeta antarctica. Polar Res 10:433-442 